\title{
Single Cell Performances Based Glass Composite Membrane for Low Temperature $\mathrm{H}_{2} / \mathrm{O}_{2}$ Fuel Cells
}

\author{
Uma Thanganathan*
}

\author{
Research Core Interdisciplinary Science (RCIS), Okayama University, Tsushima-Naka, Okayama, 700-8530, \\ Japan
}

\begin{abstract}
Membrane electrode assemblies (MEAs) for a low temperature $\mathrm{H}_{2} / \mathrm{O}_{2}$ fuel cell were fabricated using glass composite membrane and $\mathrm{Pt} / \mathrm{C}$ electrode were evaluated by various operating condition. The stability and durability of the cell and polarization characteristics of membrane electrode assembles (MEAs) were reported. Electrochemical performances on MEAs consist of PWA $\left\{\left(12\right.\right.$-tungsto(VI) phosphoric acid, $n$-hydrate)\}/ $/ \mathrm{P}_{2} \mathrm{O}_{5}\left(\right.$ phosphoric acid)/SiO ${ }_{2}$ (TEOS, tetraethoxysilane) glass composite membrane electrolyte and $\mathrm{Pt} / \mathrm{C}$ electrode have been demonstrated representing a major milestone towards developing a viable atmospheric low temperature $\mathrm{H}_{2} / \mathrm{O}_{2}$ fuel cell system. MEAs were showed good performances under various functions of the temperature and relative humidity. A maximum current density of $141 \mathrm{~mA} / \mathrm{cm}^{2}$ was obtained at $35^{\circ} \mathrm{C}$ with $30 \%$ relative humidity by using a_PWA/ $\mathrm{P}_{2} \mathrm{O}_{5} / \mathrm{SiO}_{2}(5 / 5 / 90$ mol\%) glass composite membrane and $\mathrm{Pt} / \mathrm{C}\left(0.1 \mathrm{mg} / \mathrm{cm}^{2}\right)$ electrode. Polarization curves were recorded and their results support the conclusions obtained from the electrochemical impedance spectroscopy (EIS).
\end{abstract}

Keywords: Glass, Composite, MEA, Pt/C electrode, Fuel cell, Low temperature.

\section{INTRODUCTION}

Fuel cells have been considered as promising alternative power sources due to the high conversion efficiency of the chemical energy of fuel to electrical energy with low emission of pollutants [1-3]. Fuel cells present a highly efficient and environmentally friendly alternative technology for decentralized energy production. Fuel cells offer the tantalizing promise of cleaner electricity with less impact on the environment than traditional energy conversion technologies. This is because fuel cells are direct electrochemical energy conversion devices. Proton exchange membrane fuel cells (PEMs) in general have a high power density, its ability to provide an ionic path for protons to travel from the anode to the cathode, moderately efficient in their conversion of chemical energy to electrical energy, low operating temperatures and low greenhouse gas emissions [4, 5]. Proton exchange membrane (PEM) fuel cells are one of two types of fuel cells being intensively investigated today because they have the potential to be versatile. Applications of PEM fuel cells are seen in electric utility, portable power, and transportation $[6,7]$. The low operating temperature of a $\mathrm{H}_{2} / \mathrm{O}_{2}$ PEMFC has both advantages and disadvantages.

Low temperature operation is advantageous because the cell can start from ambient conditions,

"Address correspondence to this author at the Research Core Interdisciplinary Science (RCIS), Okayama University, Tsushima-Naka, Okayama, 700-8530, Japan; Tel: +81 862518706 ; Fax: +81 862518705 ;

E-mail: ptuma2005@gmail.com quickly, especially when pure hydrogen fuel is available. It is a disadvantage in carbon monoxide containing fuel streams, because carbon will attack the platinum catalyst sites masking the catalyst activity and reducing cell performance [8]. The effect is reversible by temperatures must be greater than $120^{\circ} \mathrm{C}$, at which point there is a reduction in chemisorptions and electrooxidation. The heart of fuel cell is a device involving multi-physics coupling phenomena: mass transport (in the electrodes and electrolyte), charge transport (in the electrolyte), and electrochemical kinetics (at reactive sites). Currently there are many types of electrolyte materials for application as PEMs. However, each material has specific limitations restricting its usefulness for application to fuel cells. Current densities should be higher than $100 \mathrm{~mA} / \mathrm{cm}^{2}$ electrode area to make the fuel cell economically attractive [911]. Current density is limited by both the electrolyte resistance and the catalytic efficiency of the electrode materials.

Proton conductors have a promising future due to unique advantage such as flexibility, high mechanical strength, thermal stability, excellent processibility and high proton conductivity. For instance, perfluorosulfonated ionomer $\left(\mathrm{Nafion}^{\circledR}\right)$ membranes have been used for this purpose, due to their efficient proton conduction $\left(10^{-1} \mathrm{~S} / \mathrm{cm}\right.$ in their fully hydrated protonic form) and long lifetime [12-15]. Lower cost polymers with similar properties are strongly desired as alternative materials [16-20]. The proton conducting glass membrane was yielding high proton conductivities of $10^{-2}-10^{-1} \mathrm{~S} / \mathrm{cm}$ at room temperature $[21,22]$. A proton-conducting membrane is an integral 
part of a fuel cell system. Fuel cells offer the best alternative to conventional power generation technologies. They are inherently very efficient and clean. In our lab, electrochemical activity tests have been performed on a $\mathrm{H}_{2} / \mathrm{O}_{2}$ fuel cell fed with $\mathrm{H}_{2}$ and $\mathrm{O}_{2}$ at room temperature utilizing silica phosphate and heteropolyacid glass membranes [23]. Based on previous work, our interest is to fabricate the MEAs on cell performances operating by various operating conditions for $\mathrm{H}_{2} / \mathrm{O}_{2}$ fuel cell.

HPAs with the Keggin structure, and in particular the compounds $\mathrm{H}_{3} \mathrm{PMo}_{12} \mathrm{O}_{40}$ and $\mathrm{H}_{3} \mathrm{PMo}_{12} \mathrm{O}_{40}$ have received particular attention due to their acidic and redox properties, stability at elevated temperatures, commercial availability and relative ease of synthesis $[24,25]$. HPAs are known proton conductors, which may be exploited in the design of the membrane electrode assembly (MEA). Depending on their chemical environment not all HPA loose all their bound water molecules below $100{ }^{\circ} \mathrm{C}$, allowing the real possibility of proton conduction at elevated temperatures. These materials have even been investigated as possible electrocatalysts for fuel cell applications with limited success; they have been shown to increase the tolerance of a platinum containing anode to deactivation by carbon monoxide [26-28]. There are many HPAs that are easily synthesized that have not been investigated as PEM fuel cell electrocatalysis. This paper presents a more exhaust report on the glass composite membrane for low temperature fuel cell in order to define the MEA optimum operation and the effects of MEA preparation on the performance of a PEMFC. The objective of our research aim is to improve the cell performances by different operating conditions with glass composite membrane. The present study demonstrates the development of a $\mathrm{H}_{2} / \mathrm{O}_{2}$ fuel cell with a PWA $/ \mathrm{P}_{2} \mathrm{O}_{5} / \mathrm{SiO}_{2}$ glass composite electrolyte and a $\mathrm{Pt} / \mathrm{C}$ electrode as well as its performance at low temperature.

\section{EXPERIMENTAL SECTIONS}

The $\mathrm{PWA} / \mathrm{P}_{2} \mathrm{O}_{5} / \mathrm{SiO}_{2} \quad((5 / 5 / 90 \quad \mathrm{~mol} \%)$ glass composite membrane preparation procedures were adapted from our previous work $[23,29]$ and the preparation procedure of the catalyst layer was similar to our previous study [30]. Furthermore, PWA glasses [31] for $\mathrm{H}_{2} / \mathrm{O}_{2}$ fuel cell electrolytes were tested at room temperature and the proton conductivity of $10^{-2}$ magnitude order was obtained at $90{ }^{\circ} \mathrm{C}$ and $30 \% \mathrm{RH}$. Catalyst slurry ink composed of $\mathrm{Pt} / \mathrm{C}\left(0.1 \mathrm{mg} / \mathrm{cm}^{2}\right)$ powder, Nafion ionomer and polytetraflouroethylene
(PTFE) was sprayed onto carbon sheet as a catalyst layer. Here, used the glass composite and catalyst layer thicknesses are 0.7 and $0.20 \mathrm{~mm}$. The MEA compartments were separated by the glass ceramic electrolyte, each face of which was covered with porous $\mathrm{Pt} / \mathrm{C}$ electrode. The total thickness of MEA is $0.9 \mathrm{~mm}$. The MEA were those of a typical fuel cell with a $0.75 \mathrm{~cm}^{2}$ surface area (projected area). Each MEA compartment was sealed by a carbon cloth. The electrode was prepared with metal $\mathrm{Pt} / \mathrm{C}\left(0.1 \mathrm{mg} / \mathrm{cm}^{2}\right)$ loading at $100{ }^{\circ} \mathrm{C}$. The cell temperatures were 35,45 , $55{ }^{\circ} \mathrm{C}$, and humiliation level, $35,45,55 \%$, respectively, controlled by NF-Electrochemical fuel cell evaluation system, Japan. The gas flow rates of $50 \mathrm{~mL} / \mathrm{min}$ for oxygen to anode sides and $100 \mathrm{~mL} / \mathrm{min}$ for hydrogen to cathode sides, respectively, 1 atmospheric pressure. It was controlled by special A520 software. After the cell was conditioned, it was put on open circuit voltage $(\mathrm{OCV})$ with hydrogen and oxygen as feed gases on the anode and cathode sides, respectively. The OCV was monitored over the life of the cell during throughout the electrochemical measurement.

The catalyst layer consists of $\mathrm{Pt} / \mathrm{C}$ phase, ionomer phase and gas pore phase. During fuel cell operation, $\mathrm{O}_{2}$ reduction reaction occurs at the three-phase boundaries: where $\mathrm{O}_{2}$ from gas pores, protons from ionomer and electron from $\mathrm{Pt} / \mathrm{C}$. The total voltage losses in the catalyst layer include kinetic loss, proton/electron transport loss and $\mathrm{O}_{2}$ transport loss. All these lose are more or less dependent on the electrode composition and structure, such as $\mathrm{Pt}$ loading, $\mathrm{Pt} / \mathrm{C}$ ratio, ionomer loading and electrode porosity.

The AC impedance spectra were monitored using a Solarton 1260 frequency-response analyzer, controlled by a Solarton 1287 electrochemical interface analyzer. The impedance spectra were measured in the constant voltage mode by sweeping frequencies over the $0.1 \mathrm{~Hz}$ to $1 \mathrm{MHz}$ range, and recording 10 points/decade with voltage amplitude of $10 \mathrm{mV}$. The impedance data was carried out using the Solartron software, $Z$ view. Prior to impedance measurements to determine the current corresponding to cell voltage, typically polarization curves were recorded. Each polarization curves were displayed for $1 \mathrm{hr}$ time set after impedance spectra, the constancy of the I-V measured before and after each impedance measurements were taken as a criterion for the stability of the cell during the measurement. Two sets of polarization curves were recorded, one set is displayed as a function of temperature with constant relative humidity and another one was recorded as a function of humidity with constant temperature is $30^{\circ} \mathrm{C}$. 


\section{RESULTS AND DISCUSSION}

Figure $1(\mathbf{a}, \mathbf{b}$ and $\mathbf{c})$ shows the result of the open circuit voltage test on $\mathrm{PWA} / \mathrm{P}_{2} \mathrm{O}_{5} / \mathrm{SiO}_{2}$ glass composite membrane operating at $30 \%$ relative humidity for various temperatures $\left(35,45\right.$ and $\left.55{ }^{\circ} \mathrm{C}\right)$. Figure $1 \mathrm{a}$, the cell started the OCV at about $0.75 \mathrm{~V}$ and then reached to $1 \mathrm{~V}$ with $1 \mathrm{~h}$ time. The cell was operated in $6 \mathrm{~h}$. After $6 \mathrm{~h}$ operation, the OCV of the cell was 0.95 $\mathrm{V}$. By testing, all the temperatures, OCVs, above $0.9 \mathrm{~V}$ were obtained. Figure 1 (b and c) shows the similar trend, and they were confirmed the cell was constantly stable after $1 \mathrm{hr}$ and shows good OCV for fuel cell test. The strength of MEA was very important to show the good performances in the $\mathrm{H}_{2} / \mathrm{O}_{2}$ fuel cell. Here we have
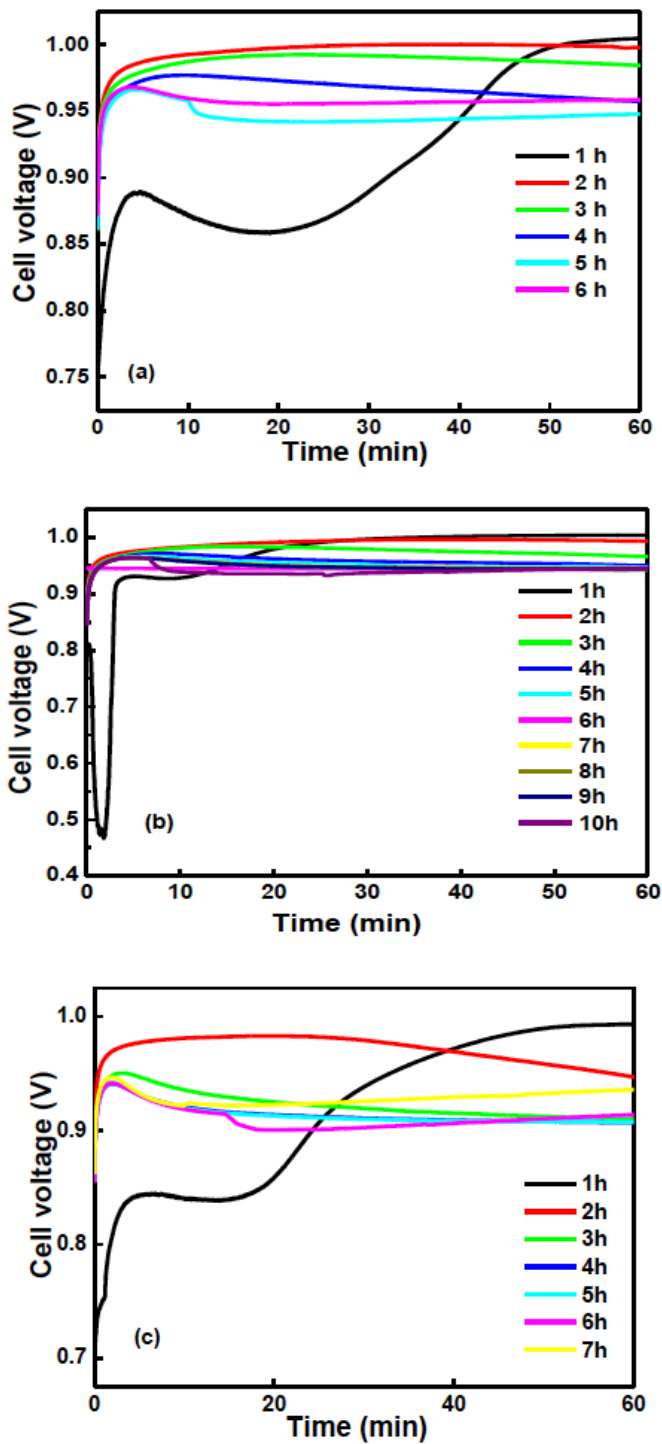

Figure 1: Time vs cell voltage curves for $\mathrm{PWA} / \mathrm{P}_{2} \mathrm{O}_{5} / \mathrm{SiO}_{2}$ glass composite membrane measured at various temperatures condition with $30 \%$ relative humidity: (a) 35 , (b) 45 and (c) $55^{\circ} \mathrm{C}$. run the OCV for $10 \mathrm{~h}$ at $55{ }^{\circ} \mathrm{C}$, without any degradation, and recorded the high performances. Figure 2 (a, b and $\mathbf{c}$ ) shows the OCV at $0.5 \mathrm{~V}$ for $\mathrm{PWA} / \mathrm{P}_{2} \mathrm{O}_{5} / \mathrm{SiO}_{2}$ glass membrane were operated at 30 ${ }^{\circ} \mathrm{C}$ with three humidity conditions $(30,40,50 \%)$. For these three tests, the observation shows the OCV was stable and the trend was similar as Figure 1 . The operating time was 2, 3 and $5 \mathrm{~h}$ (Figure $\mathbf{2}(\mathbf{a}, \mathbf{b}$ and $\mathbf{c})$ ), the cell voltage were decreased after $1 \mathrm{~h}$, so the experiments were stopped. However, the variation of cell voltage loss due to the ohmic resistance, that was recorded. From those observation on OCV, further can improved the cell voltage can be increased by changes of gas flow rates to the anode and cathode sections, respectively.
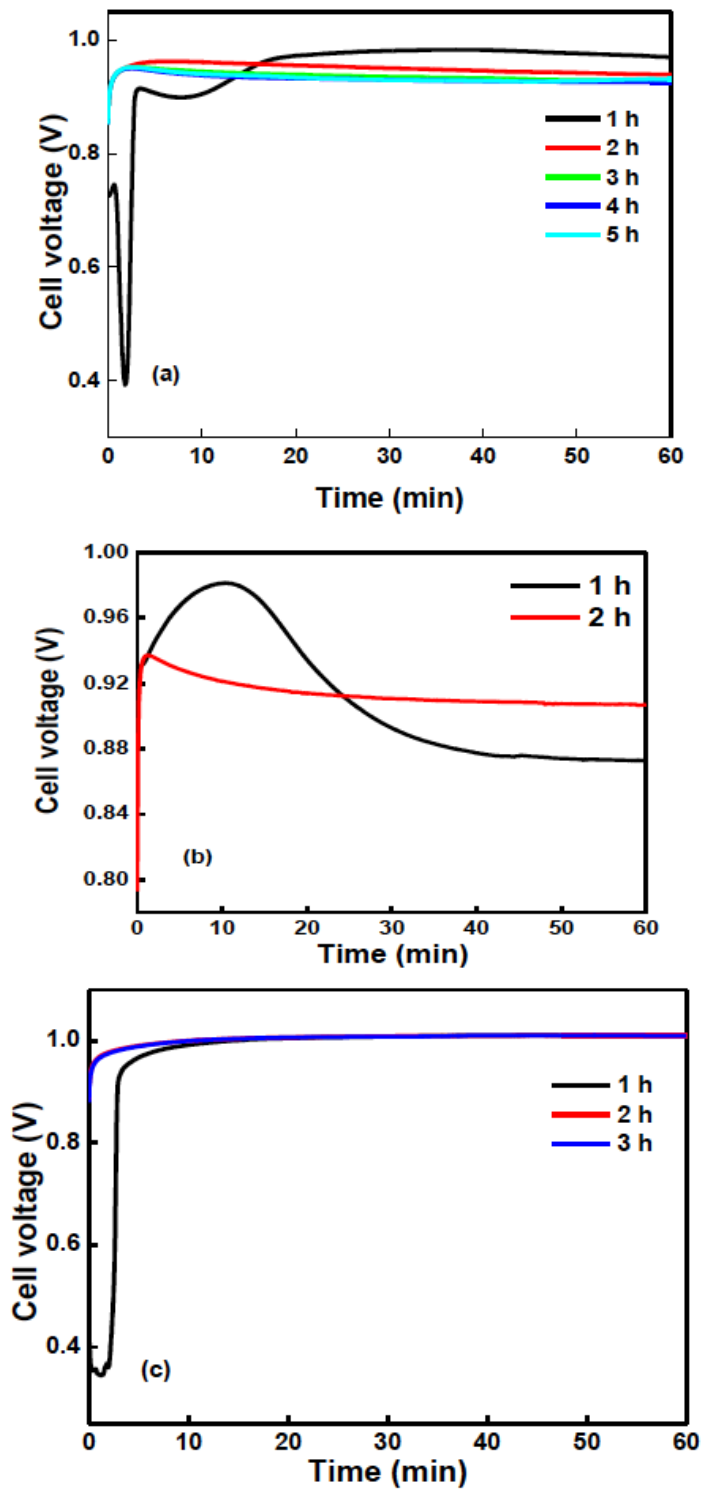

Figure 2: Time vs cell voltage curves for $\mathrm{PWA} / \mathrm{P}_{2} \mathrm{O}_{5} / \mathrm{SiO}_{2}$ glass composite membrane measured at various humidity condition with $30{ }^{\circ} \mathrm{C}$. (a) 35 , (b) 45 and (c) $55 \%$. 
Fuel cell tests were carried using the $0.9 \mathrm{~mm}$ thick MEA between 35 and $55{ }^{\circ} \mathrm{C}$ under constant humidified $(30 \%)$ condition. The current-voltage (I-V) curves of the fuel cell are shown in Figure 3. All the current-voltage slopes became lower as the operating time increased. The power density value of $38.5 \mathrm{~mW} / \mathrm{cm}^{2}$ and current density value of $141 \mathrm{~mA} / \mathrm{cm}^{2}$ at $35{ }^{\circ} \mathrm{C}$ with $30 \%$ relative humidity were obtained for $4 \mathrm{~h}$ (Figure $3 \mathrm{a}$ ). The cell performance was increased with increase the cell temperature at $45{ }^{\circ} \mathrm{C}$, the power density was 41.5 $\mathrm{mW} / \mathrm{cm}^{2}$ at $108 \mathrm{~mA} / \mathrm{cm}^{2}$ (Figure 3b). Further, the maximum power density was reached $51 \mathrm{mWcm}^{2}$ at 55 ${ }^{\circ} \mathrm{C}$ and current density was $198 \mathrm{~mA} / \mathrm{cm}^{2}$ for $4 \mathrm{~h}$ measurement, after that both values were decreased
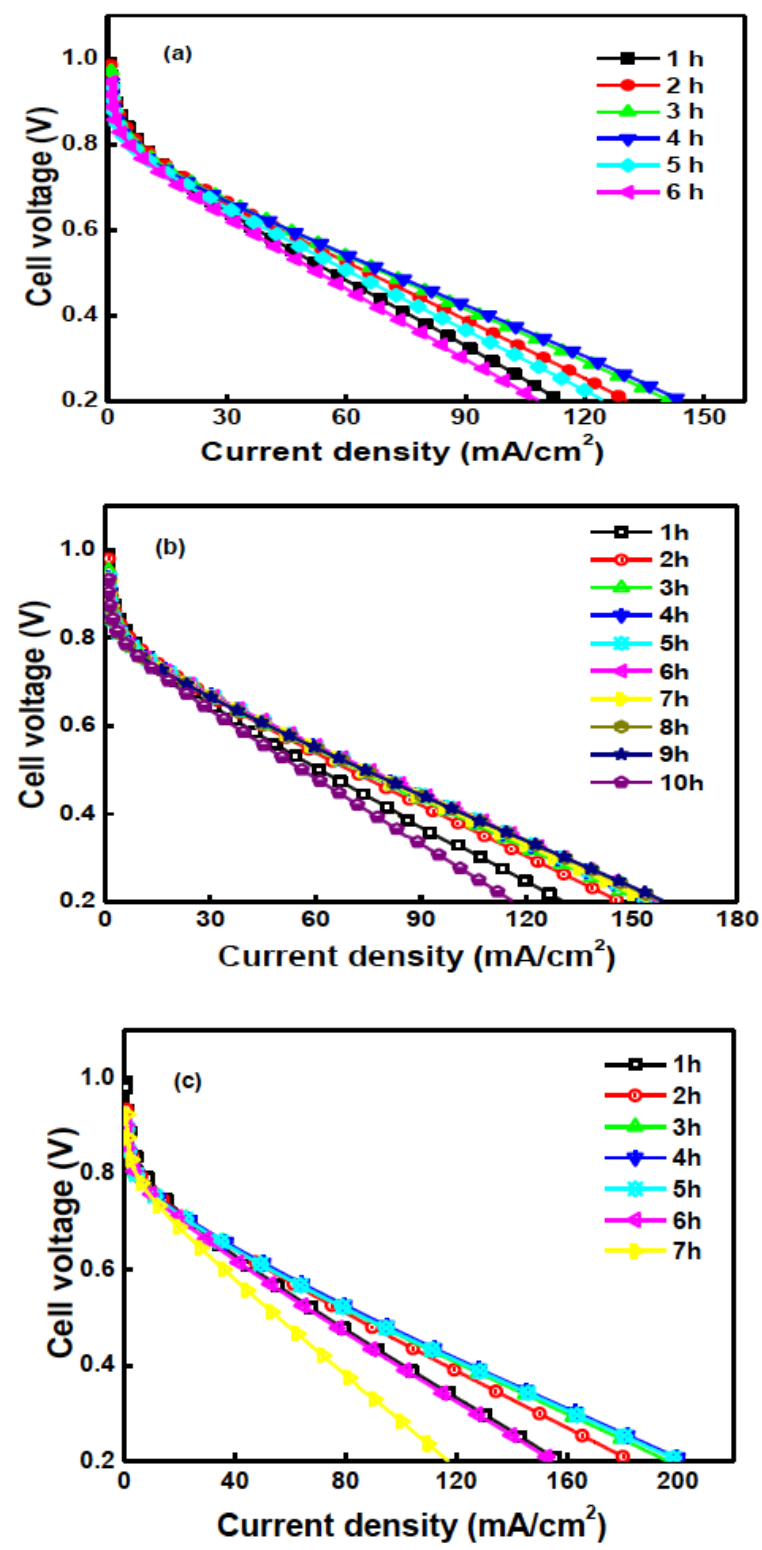

Figure 3: $1-\mathrm{V}$ curves for $\mathrm{PWA} / \mathrm{P}_{2} \mathrm{O}_{5} / \mathrm{SiO}_{2}$ glass composite membrane measured at various temperature conditions with $30 \%$ relative humidity: (a) 35 , (b) 45 and (c) $55^{\circ} \mathrm{C}$.
(Figure 3c) and also observed the cell voltage decreased from $1 \mathrm{~V}$ to $0.9 \mathrm{~V}$. However the performances are higher compared to previous work at low temperature using the same glass composite membrane [23].

Figure 4 and 5 show the polarization curves for $\mathrm{PWA} / \mathrm{P}_{2} \mathrm{O}_{5} / \mathrm{SiO}_{2}$ glass composite membrane in $\mathrm{H}_{2} / \mathrm{O}_{2}$ fuel cell at various humidity conditions. Hydrogen and oxygen was flow to the anode and cathode compartment at $50-100 \mathrm{~mL} / \mathrm{min}$ at $1 \mathrm{~atm}$ pressure. At $30{ }^{\circ} \mathrm{C}$ and $30 \% \mathrm{RH}$, the cell resistance was $3.9 \mathrm{ohm}$ $\mathrm{cm}^{2}$ and the maximum power and current density values of $30.5 \mathrm{~mW} / \mathrm{cm}^{2}$ and $120 \mathrm{~mA} / \mathrm{cm}^{2}$, respectively, for $4 \mathrm{~h}$ measurement, after that those values were decreased including cell voltage from $0.78 \mathrm{~V}$ to $0.98 \mathrm{~V}$ (Figure $\mathbf{4 a}$ and $\mathbf{5 a}$ ). The humidity conditions were increased from 30 to 40 and $50 \%$ and observed the cell performances, at similar operating conditions; the power density values were increased 33 and 38 $\mathrm{mW} / \mathrm{cm}^{2}$ at $0.5 \mathrm{~V}$ and also current density values were increased [Figure $4(b, c)$ and $5(b, c)$ ]. Fuel cell polarization curves increase with increasing operating time. Conversely, the polarization curves decrease with decreasing operating time. The current-voltage curves are linear, typical of a cell with high internal resistance. The increase in temperature and humidity level, results the cell performances were improved, but the values are not high like Nafion membrane was showed higher performances at low and high temperature fuel cells $[32,33]$. This power density was considered to be the highest output presently known when using the $\mathrm{PWA} / \mathrm{P}_{2} \mathrm{O}_{5} / \mathrm{SiO}_{2}$ glass composite membrane with a 0.1 $\mathrm{mg} / \mathrm{cm}^{2} \mathrm{Pt} / \mathrm{C}$ electrode in $\mathrm{H}_{2} / \mathrm{O}_{2}$ fuel cells at low temperatures.

During the same experimental conditions (electrical potential $0.5 \mathrm{~V}$ ), the distance between the end of the platinum wires and the edge of active electrodes of the fuel cell was always much larger than three times the thickness of the glass membrane to avoid potential gradients. The chemical reaction of PWA containing glass membrane with hydrogen is due to the reduction of PWA species to a heteropolyblue compound that is a mixed-valence intervalence transition. The heteropolyblue species have the same structure as the parent heteropolyacid but they are characterized by a tungsten atom in the Keggin structure having $5^{+}$ oxidation state. The reduced PWA species migrate to the cathode in the PWA cell where they are reoxidized by dissolved oxygen. The evidence of a chemical reaction of $\mathrm{H}_{2}$ with phosphotungstic acid is strongly supported by the observed color change of the 

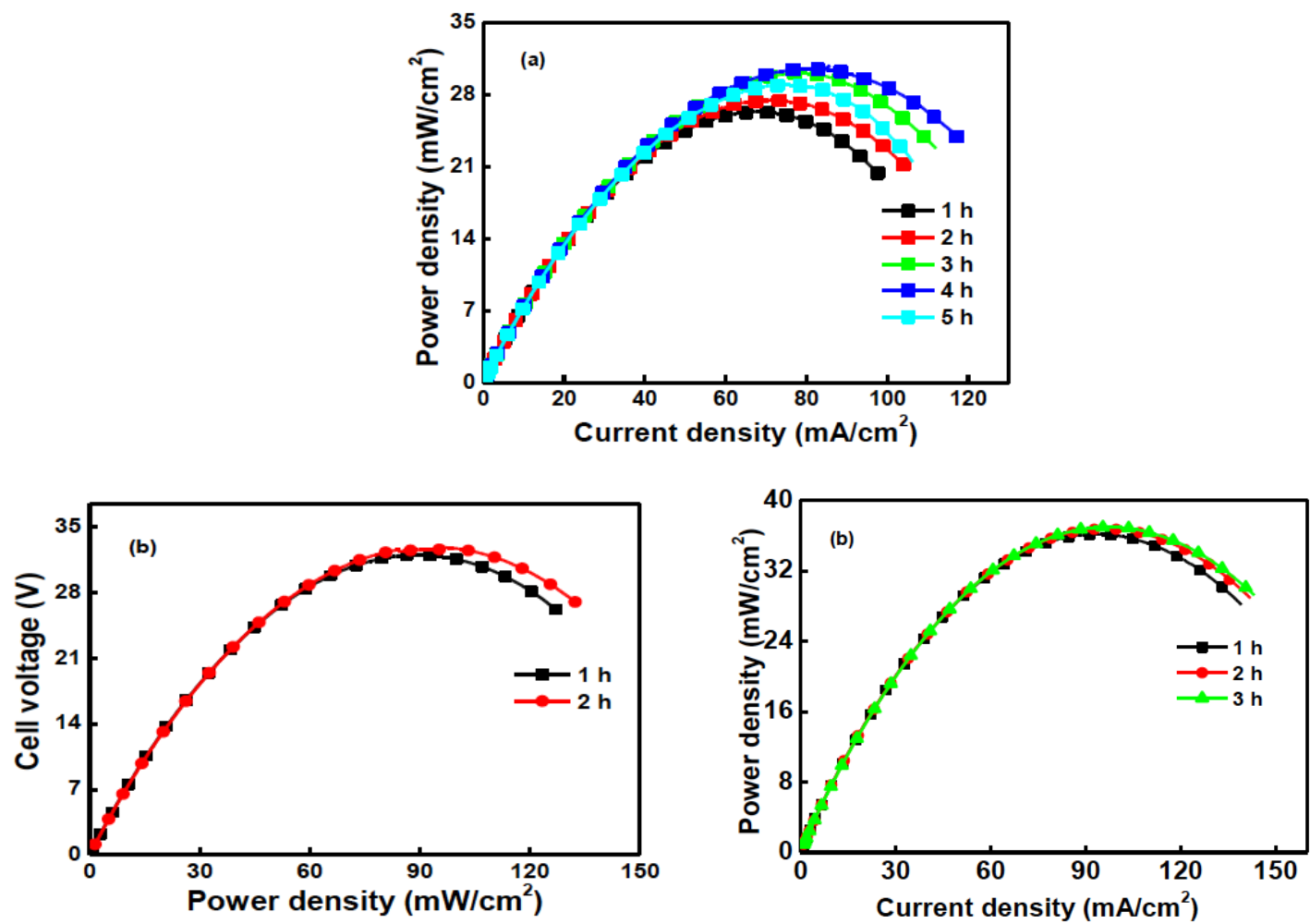

Figure 4: Polarization curves for $\mathrm{PWA} / \mathrm{P}_{2} \mathrm{O}_{5} / \mathrm{SiO}_{2}$ glass composite membrane measured at various humidity conditions with 30 ${ }^{\circ}$ C. (a) 35, (b) 45 and (c) $55 \%$.
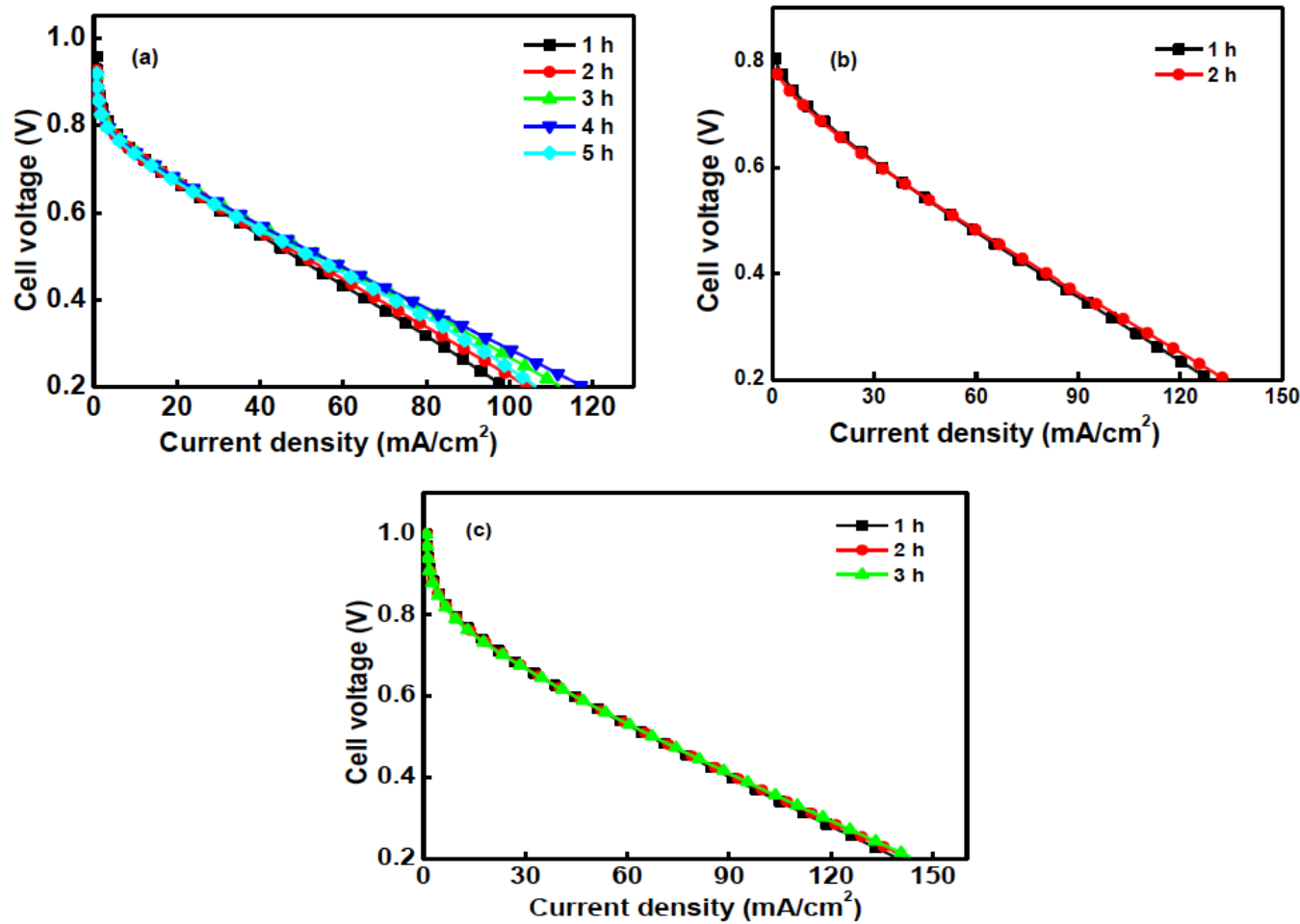

Figure 5: I-V curves for $\mathrm{PWA} / \mathrm{P}_{2} \mathrm{O}_{5} / \mathrm{SiO}_{2}$ glass composite membrane measured at various humidity conditions with $30{ }^{\circ} \mathrm{C}$. (a) 35 , (b) 45 and (c) $55 \%$.

electrolyte coming out from the anodic side of the cell, from colorless to a deep blue color, which can be explained by the formation of reduced PWA species [20]. 
Figure 6 (a-c) present typical complex impedances obtained at cell voltage $0.5 \mathrm{~V}$ for electrode with a content of $\mathrm{Pt} / \mathrm{C}\left(0.1 \mathrm{mg} / \mathrm{cm}^{2}\right)$. The effect of temperature on the EIS system was measured with constant humidity condition at $30 \%$. The strong dependence of temperature provides the reports on EIS behavior of $\mathrm{H}_{2} / \mathrm{O}_{2}$ fuel cell reveal the presence of two loops. The higher frequency intercepts of the kinetic loop and the real impedance axis is a measure of the total ohmic resistance of the cell. The total resistance can be
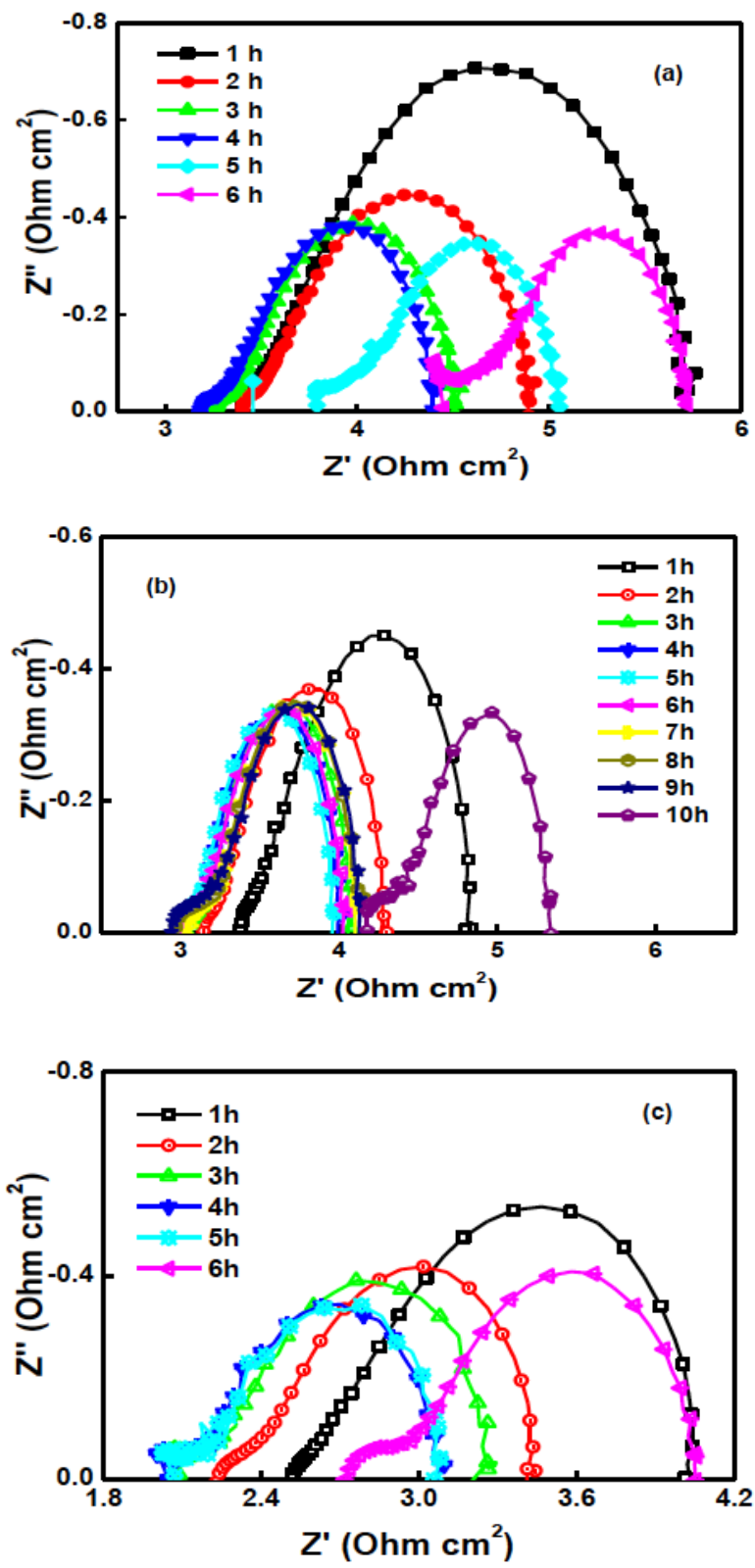

Figure 6: A.C impedance spectrum measured at various temperature conditions: (a) 35, (b) 45 and (c) $55{ }^{\circ} \mathrm{C}$ with relative humidity for $\mathrm{PWA} / \mathrm{P}_{2} \mathrm{O}_{5} / \mathrm{SiO}_{2}$ glass composite membrane. expressed as a sum of the contributions from contact resistances and ohmic resistances of the cell components including membrane, catalyst layer and gas diffusion layer [34], among which, the biggest contributor is the membrane resistance. Another series of experiments was performed by changing the humidification and keeping fixed cell temperature is 30 ${ }^{\circ} \mathrm{C}$ during electrochemical measurements. The observed changes results of ohmic resistance values were noted from Figure 7. The shape of loops is similar as Figure 6, one is small loop and second one is big loop. In our experiment, both effects were small, since the operating temperature was low and the humidification also moderate. The semicircle of the high frequency region, as seen in Figure 7 , was not included because this semicircle at the high frequency region is not associated with the electrode process [35]. The loop at the lower frequency region corresponds to the electrode process and the loop at the higher frequency region is not associated with electrode process. Freire and Gonzalez [36] measured the Ohmic resistances at different currents by Ac impedance through the high frequency intercepts values of the kinetic loop. Their results indicated that the Ohmic resistances, mainly membrane resistances change with current. On the contrary, comparison of both effects on EIS recorded in similar condition at different temperature $\left(35-55^{\circ} \mathrm{C}\right.$ ) and humidity (35$55 \%$ ) revealed little different shapes of loops at low and high frequency region. The ohmic resistance values were obtained for both experiments in the range from 2 to $4 \mathrm{ohm} / \mathrm{cm}^{2}$. However, we emphasize that the $\mathrm{PWA} / \mathrm{P}_{2} \mathrm{O}_{5} / \mathrm{SiO}_{2}$ glass ceramic composite membrane sample showed a low resistance of $1.38 \mathrm{ohm} / \mathrm{cm}^{2}$, while maintaining a high OCV of $0.9 \mathrm{~V}$.

Performing AC-impedance measurements on fuel cells can assist in identifying problems within the fuelcell components as well as track deviations in the fuel cell assembly process. More specifically, such measurements can be helpful in identifying the kinetic resistances in the fuel cell system and the ohmic resistances in the system and in the electrolytic. Fuel cell components that can affect the impedance include current collectors, porous electrodes, the catalytic layer and the membrane. When the temperature was increased from 35 to $55{ }^{\circ} \mathrm{C}$, there is no further decrease in ohmic resistance, suggesting that the membrane resistance is no longer the main contributor to the ohmic resistance. However, the charge transfer resistance decreases consistently with the increase of temperature and humidity. 

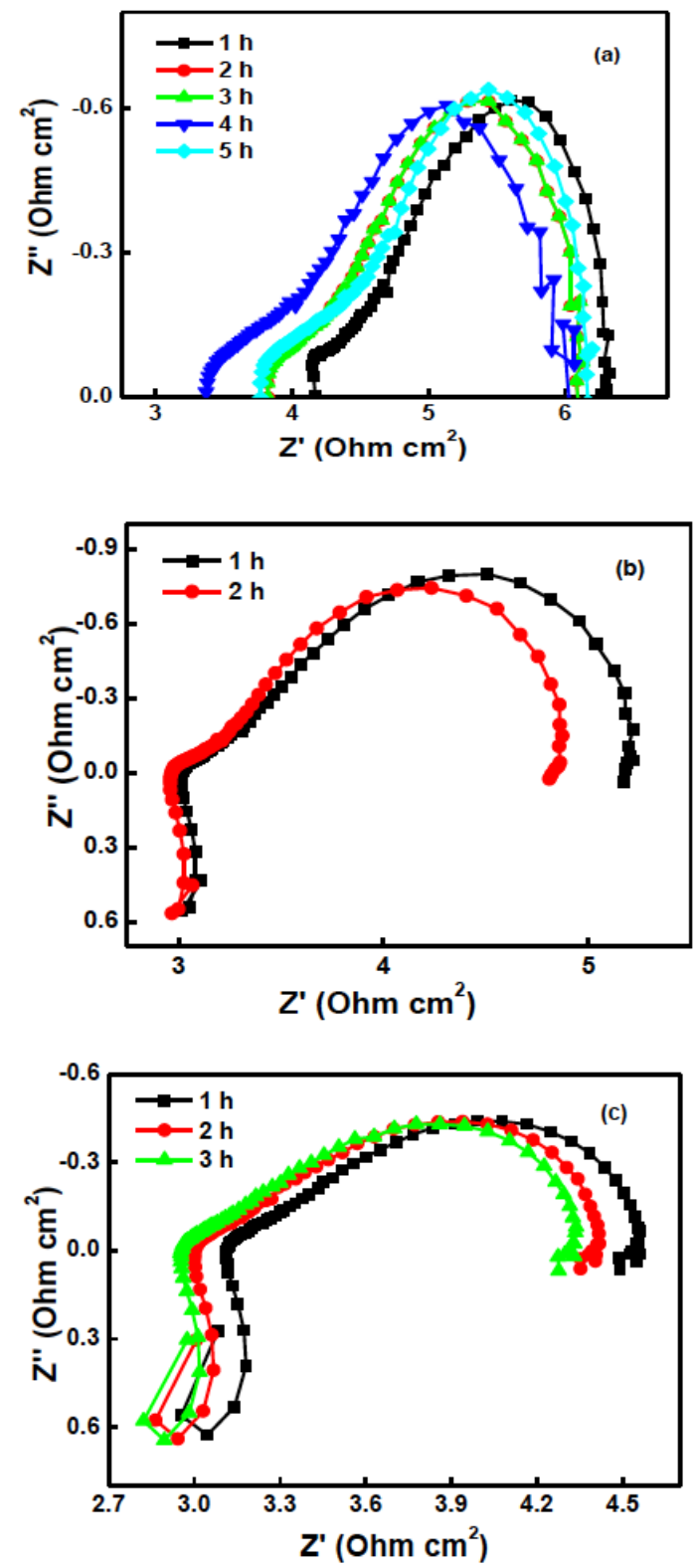

Figure 7: A.C impedance spectrum measured at various humidity conditions: (a) 35, (b) 45 and (c) $55 \%$ for $\mathrm{PWA} / \mathrm{P}_{2} \mathrm{O}_{5} / \mathrm{SiO}_{2}$ glass composite membrane at $30^{\circ} \mathrm{C}$.

\section{SUMMARY}

Because of our interest we measured the cell resistance value at various potential using a good MEA, its only showed high performance, because of heteropolyacid in the phosphosilicate glass. Further in future, require to study about the effect of heteropolyacids in glass composite how could be affected at similar operating condition for $\mathrm{H}_{2} / \mathrm{O}_{2}$ fuel cell. Our EIS results showed the ohmic resistance of the electrolyte and electrode which can be estimated from the high and low frequency limit of the spectrum. Operating at low temperature under constant atmospheric pressure, the cell delivers a maximum power density of about $51 \mathrm{~mW} / \mathrm{cm}^{2}$ and a current of $198 \mathrm{~mA} / \mathrm{cm}^{-2}$ at $55{ }^{\circ} \mathrm{C}$ and $30 \% \mathrm{RH}$. These values are high and promising, and suggest that the $\mathrm{PWA} / \mathrm{P}_{2} \mathrm{O}_{5} / \mathrm{SiO}_{2}$ glass composite membranes are suitable for use in low temperature $\mathrm{H}_{2} / \mathrm{O}_{2}$ fuel cells. This work thus imparts a distinctive opportunity to improve fuel cell performances by tuning the glass composite membrane properties through optimization and using non-noble metals as electrode.

\section{ACKNOWLEDGEMENTS}

This work was financially supported by the Ministry of Education, Sport, Culture, Science and Technology (MEXT) and the Special Coordination Funds for Promoting Sciences and Technology of Japan.

\section{REFERENCES}

[1] Ralph TR, and Hards GA, "Powering the cars and homes of tomorrow", Chem Ind 1998; 9: pp. 337-342.

[2] Preli F. "Technical Challenges for Fuel Cells in Mobile Applications", Fuel Cells 2002; 2: pp. 5-9. https://doi.org/10.1002/1615-6854(20020815)2:1<5::AIDFUCE5 $>3.0 . \mathrm{CO} ; 2-3$

[3] Dyer CK. "Fuel cells for portable applications", J Power Sources 2002; 106: pp. 31-34. https://doi.org/10.1016/S0378-7753(01)01069-2

[4] Zhang $\mathrm{H}$ and Shen PK. "Recent Development of Polymer Electrolyte Membranes for Fuel Cells", Chem Rev 2012; 112 pp. $2780-2832$.

https://doi.org/10.1021/cr200035s

[5] Khalfan AS, Ibrahim SA, Haining Z and Mu P. Functionalized polysulfones as an alternative material to improve proton conductivity at low relative humidity fuel cell applications", Chemistry and Materials Research 2014; 6: pp. 19-29.

[6] Song C. "Fuel processing for low-temperature and hightemperature fuel cells Challenges, and opportunities for sustainable development in the 21st century", Catalysis today $2002 ; 77$ : pp. 17-49. https://doi.org/10.1016/S0920-5861(02)00231-6

[7] Strasser K. "Mobile fuel cell development at Siemens", J Power Sources 1992; 37: pp. 209-219. https://doi.org/10.1016/0378-7753(92)80079-Q

[8] Ernst WD. "PEM Technology development at plug power", 2000 fuel cell seminar program and abstracts, Portland Oregon, Sponsored by Fuel cell seminar Organizing Committee, October 30-November 2: 2000.

[9] Heo P, Nagao M, Sano M and Hibino T. "A high-performance $\mathrm{Mo} 2 \mathrm{C}-\mathrm{ZrO} 2$ anode catalyst for intermediate temperature fuel cells", J Electrochem Soc 2007; 154: pp. B53-B56. https://doi.org/10.1149/1.2382268

[10] Richman S, Burstein L and Peled E. "Novel proton exchange membrane based on single-step preparation of functionalized ceramic powder containing surface-anchored sulfonic acid", J Power Sources 2008; 179: pp. 520-531. https://doi.org/10.1016/j.jpowsour.2007.12.127

[11] Tian J, Sun G, Cai M, Mao $Q$ and Xin Q. "PtTiOx/C electrocatalyst with improved durability in $\mathrm{H} 2 / \mathrm{O} 2$ PEMFCs without external humidification", J Electrochem Soc 2008; 155: pp. B187-B193.

https://doi.org/10.1149/1.2816290 
[12] Zawodzinski TA, Neeman M, Sillerud LO and Gottesfeld S. "Determination of water diffusion-coefficients in perfluorosulfonate ionomeric membranes", J Phys Chem 1991; 95: pp. 6040-6044.

https://doi.org/10.1021/j100168a060

[13] Sone Y, Ekdunge P and Simonsson DJ. "Proton conductivity of nafion 117 as measured by a four-electrode ac impedance method", J Electrochem Soc 1996; 4: pp. 1254-1259. https://doi.org/10.1149/1.1836625

[14] Silva RF, De Francesco $M$ and Pozio A. "Tangential and normal conductivities of nafion ${ }^{\circledR}$ membranes used in polymer electrolyte fuel cells", J Power Sources 2004; 134: pp. 18-26. https://doi.org/10.1016/j.jpowsour.2004.03.028

[15] Fontanella JJ, Edmondson CA, Wintersgill $M, W u ~ Y$ and Greenbaum SG. "High-pressure electrical conductivity and nmr studies in variable equivalent weight nafion membranes", Macromolecules 1996; 29: pp. 4944-4951. https://doi.org/10.1021/ma9600926

[16] Miyateke K, Shouji E, Yamamoto K and Tsuchida E. "Synthesis and proton conductivity of highly sulfonated poly(thiophenylene)", Macromolecules 1997; 30: pp. 29412946.

https://doi.org/10.1021/ma961830t

[17] Wycisk R and Pintauro PN. "Sulfonated polyphosphazene ion-exchange membranes", J Membr Sci 1996; 199: pp. 155160.

https://doi.org/10.1016/0376-7388(96)00146-9

[18] Wang F, Chen T, Xu J. "Synthesis of poly (ether ether ketone) containing sodium sulfonate groups as gas dehumidification membrane material", Macromol Rapid Commun 1998; 19: pp. 135-137. https://doi.org/10.1002/(SICI)15213927(19980201)19:2<135::AID-MARC135>3.0.CO;2-7

[19] Nikitina TS. " $\alpha \beta \beta$-trifluorostyrene and polymers based on it", Rus Chem Rev 1990; 59: pp. 575-579. https://doi.org/10.1070/RC1990v059n06ABEH003544

[20] Przyluski J, Poltarzewski Z and Wieczorek W. "Protonconducting hydrogel membranes", Polymer 1998; 39: pp. 4343-4347. https://doi.org/10.1016/S0032-3861(97)00525-9

[21] Nogami M, Matsushita YH, Goto $Y$ and Kasuga T. "Sol-gel derived glass as a fuel cell electrolyte", Advanced Materials 2000; 12: pp. 1370-1372. https://doi.org/10.1002/1521-4095(200009)12:18<1370::AIDADMA1370>3.0.CO;2-1

[22] Uma $T$ and Nogami M. "A highly proton conducting novel glass electrolyte", Analytical Chemistry 2008; 80: pp. 506508. https://doi.org/10.1021/ac0706630

[23] Uma $T$ and Nogami M. "Synthesis and characterization of $\mathrm{P} 2 \mathrm{O} 5-\mathrm{SiO} 2-\mathrm{X}$ ( $\mathrm{X}=$ phosphotungstic acid) glasses as proton conducting electrolyte for $\mathrm{H} 2 / \mathrm{O} 2$ fuel cell in low temperature", J Membr Sci 2006; 280: pp. 744-751. https://doi.org/10.1016/j.memsci.2006.02.033

[24] Hayakawa N, Okuhara T, Misono $M$ and Moneda $Y$. "Catalysis by heteropoly compounds 2. Dehydration of 2Propanol over heteropolyacids and their salts", Nipón
Kagaku Kaishi 1982; 3: pp. 356-362.

$$
\text { https://doi.org/10.1246/nikkashi.1982.356 }
$$

[25] Okuhara T, Kasai A, Hayakawa N, Misono M and Yoneda $Y$ "The important role of the bulk of 12-tungtophosphoric acid in the catalytic dehydration of alcohols to olefins", Chem Lett 1981; 391: pp. 13-15.

[26] Moic UB, Milonjic SK, Malovic D, Samankovic V, Colomban $\mathrm{P}$, Mitrovic MM and Dimitrijevic R. "Structure and proton conductivity of 12-tungstophosphoric acid doped silica", Solid State Ionics 1997; 97: pp. 239-246. https://doi.org/10.1016/S0167-2738(97)00089-1

[27] Nagai $M$ and Park $Y$. "Proton-conducting properties of inorganic-organic nanocomposites proton-exchange nanocomposite membranes based on 3glycidoxypropyltrimethoxysilane and tetraethylorthosilicate", J Electrochem Soc 2001; 148: pp. A 616-A623.

[28] Staiti P, Minutoli M and Hovevar S. "Membranes based on phosphotungstic acid and polybenzimidazole for fuel cell application", J Power Sources 2000; 90: pp. 231-235.

https://doi.org/10.1016/S0378-7753(00)00401-8

[29] Uma T and Nogami M. "High performance of $\mathrm{H} 2 / \mathrm{O} 2$ fuel cells using $\mathrm{Pt} / \mathrm{C}$ electrodes and $\mathrm{P} 2 \mathrm{O} 5-\mathrm{SiO} 2-\mathrm{PMA}$ glasses as an electrolyte in low temperature", J Ceramic Society of Japan, 2006; 114: pp. 748-753.

https://doi.org/10.2109/jcersj.114.748

[30] Uma T and Nogami M. "Fabrication and performance of Pt/C electrodes for low temperature $\mathrm{H} 2 / \mathrm{O} 2$ fuel cells", J Membrane Science 2007; 302: pp. 102-108. https://doi.org/10.1016/j.memsci.2007.06.048

[31] Uma $T$ and Nogami M. "A novel glass membrane for low temperature $\mathrm{H} 2 / \mathrm{O} 2$ fuel cell electrolytes", Fuel cells 2007; 7 : pp. 279-284. https://doi.org/10.1002/fuce.200700006

[32] Curtin DE, Lousenberg RD, Henry TJ, Tangeman PC and Tisack ME. "Advanced materials for improved PEMFC performance and life", J Power Sources 2004; 131: pp. 4148.

https://doi.org/10.1016/j.jpowsour.2004.01.023

[33] Smitha B, Sridar S and Khan AA. "Solid polymer electrolyte membranes for fuel cell applications-a review", J Membr Sci 2005; 259: pp. 10-36. https://doi.org/10.1016/j.memsci.2005.01.035

[34] Lu F, Yi B, Yu J, Hou Z and Fu Y. "Development of nove self-humidifying composite membranes for fuel cells", J Power Sources 2003; 124: pp. 81-89.

https://doi.org/10.1016/S0378-7753(03)00616-5

[35] Yuan X, Sun JC, Blanco M, Wang H, Zhang $\mathrm{J}$ and Wilkinson DP. "AC impedance diagnosis of a $500 \mathrm{~W}$ PEM fuel cell stack: Part I: Stack impedance", J Power Sources 2006; 161: pp. 920-928.

https://doi.org/10.1016/j.jpowsour.2006.05.003

[36] Freire TJP, Gonzalez ER. "Effect of membrane characteristics and humidification conditions on the impedance response of polymer electrolyte fuel cells", J Electroanal Chem 2001; 503: pp. 57-68. https://doi.org/10.1016/S0022-0728(01)00364-3

Received on 14-10-2018

Accepted on 26-11-2018

Published on 13-12-2018

\section{http://dx.doi.org/10.15379/2410-1869.2018.05.02.01}

(c) 2018 Uma Thanganathan; Licensee Cosmos Scholars Publishing House.

This is an open access article licensed under the terms of the Creative Commons Attribution Non-Commercial License

(http://creativecommons.org/licenses/by-nc/3.0/), which permits unrestricted, non-commercial use, distribution and reproduction in any medium, provided the work is properly cited. 